\title{
Analysis of Temperature Modulation of Plant Defense Against Biotrophic Microbes
}

\author{
Yi Wang, Zhilong Bao, Ying Zhu, and Jian Hua \\ Department of Plant Biology, Cornell University, Ithaca, NY 14853, U.S.A. \\ Submitted 10 December 2008. Accepted 13 January 2009.
}

\begin{abstract}
Plant-pathogen interactions are known to be affected by environmental factors including temperature; however, the temperature effects have not been systematically studied in plant disease resistance. Here, we characterized the effects of a moderate increase in temperature on resistance to bacterial pathogen Pseudomonas syringae and two viral elicitors in Arabidopsis thaliana and Nicotiana benthamiana. Both the basal and the resistance $(R)$ gene-mediated defense responses to Pseudomonas syringae are found to be inhibited by a moderately high temperature, and hypersensitive responses induced by $R$ genes against two viruses are also reduced by an increase of temperature. These indicate that temperature modulation of defense responses to biotrophic and hemibiotrophic pathogens might be a general phenomenon. We further investigated the roles of two small signaling molecules, salicylic acid and jasmonic acid, as well as two defense regulators, $E D S 1$ and $P A D 4$, in this temperature modulation. These components, though modulated by temperature or involved in temperature regulation or both, are not themselves determinants of temperature sensitivity in the defense responses analyzed. The inhibition of plant defense response by a moderately high temperature may thus be mediated by other defense signaling components or a combination of multiple factors.
\end{abstract}

Plant-pathogen interactions are modulated by environmental factors that could affect both pathogenicities and host defense responses (Browder 1985; Colhoun 1973). Temperature is known to influence disease resistance to bacteria, fungi, virus, and insects, and different host-pathogen interactions respond differently to different temperature ranges (Garrett et al. 2006). A high temperature very often inhibits disease resistance (Dropkin 1969), although a low temperature is found to reduce plant defense as well (Szittya et al. 2003).

Extensive studies on plant disease resistance has revealed that it has multiple layers (Chisholm et al. 2006; Jones and Dangl 2006) and can be largely divided into basal and resistance $(R)$ gene-mediated resistance. The largest family of $\mathrm{R}$ proteins are nucleotide binding-leucine rich repeat (NB-LRR) molecules with either a coiled-coil (CC) domain or a toll-interleukin-1 receptor (TIR) domain at the N terminus (Dangl and Jones 2001; Martin et al. 2003). EDS1 (ENHANCED DISEASE SUSCEPTIBILITYI) and PAD4 (PHYTOALEXIN DEFICIENT4) are required for defense responses mediated by the TIR type of

Corresponding author: Jian Hua; E-mail: jh299@ cornell.edu

* The $\boldsymbol{e}$-Xtra logo stands for "electronic extra" and indicates that a supplemental table is published online and that Figures 5 and 6 appear in color online.
$R$ genes as well as basal disease resistance (Wiermer et al. 2005). EDS1 and PAD4 are lipase-like proteins and they physically interact with each other to function. The salicylic acid (SA) pathway is an essential part in the defense response network (Durrant and Dong 2004). SA is upregulated during the hypersensitive response (HR) to induce expression of defense effector molecules such as $P R-1$. While SA is required for both local and systemic defense response to biotrophics that feed on live host cells, jasmonic acid (JA) and ethylene are regulators of plant defense responses against necrotrophic pathogens that kill host cells (Glazebrook 2005). A number of JA signaling components have been identified. COII mediates almost all JA responses and it encodes an F-box protein that targets JAZ repressors for degradation for JA signaling (Chini et al. 2007; Thines et al. 2007; Turner et al. 2002). JARl encodes a JAamino synthetase that may generate the active form of JA (Staswick et al. 2002). Extensive interactions between SA and JA pathways have been observed, with most of them antagonistic and some synergistic (Beckers and Spoel 2006; Kunkel and Brooks 2002). The mutual inhibition between SA and JA signaling results in an apparent tradeoff between plant defenses against biotrophic and necrotrophic pathogens. However, this antagonism is regulated both temporally and spatially to reduce undesirable tradeoff when plants encounter multiple pathogen attacks (Spoel and Dong 2008; Spoel et al. 2007).

Heat sensitivity has been found in some defense responses against biotrophic and hemibiotrophic microbes. The tobacco $N$ gene mediates resistance to Tobacco mosaic virus (TMV), and the resistance is reversibly inactivated at elevated temperatures of $28^{\circ} \mathrm{C}$ or above (Samuel 1931). This temperature-sensitivity property of $N$ is retained in tomato (Whitham et al. 1996). The $M i-1$ gene in tomato confers resistance to root-knot nematodes, and the resistance is inactive above $28^{\circ} \mathrm{C}$ (Hwang et al. 2000; Jablonska et al. 2007). The Arabidopsis RPW8 gene against powdery mildew induces HR-like lesions when expressed as a transgene, and these lesions are suppressed by environmental variations including a temperature above $30^{\circ} \mathrm{C}$ (Xiao et al. 2003). The NB-LRR type of $R$-like gene $S N C 1$, when activated, induces defense responses at $22^{\circ} \mathrm{C}$ but not at a higher temperature of $28^{\circ} \mathrm{C}$ in Arabidopsis (Yang and Hua 2004). $C f 4$ and $C f 9$ are tomato $R$ genes against fungal pathogen Cladosporium fulvum, and $\mathrm{HR}$ mediated by these two genes can be suppressed at $33^{\circ} \mathrm{C}$ (de Jong et al. 2002). Thus, moderately elevated temperature could inhibit defense responses, including HR mediated by a number of $R$ genes.

It is unclear how prevalent this phenomenon is because no systemic studies have been carried out to specifically investigate temperature effects on different plant-pathogen interactions. If, indeed, plant-pathogen interactions are often modulated by temperature, this temperature sensitivity would pose a challenge to agriculture. The current climate change does 
appear to cause increased range and severity of plant diseases (Evans et al. 2008). Thus, it is both fundamental and practical to understand the scope and the molecular basis for temperature modulation of defense response. A common mechanism may exist for different systems of disease resistance, because many of them share similar signaling molecules and use similar signaling mechanisms. Some of the signaling components are themselves modulated by temperature. SA is found to function in both chilling and heat shock responses in addition to its well-established roles in biotic responses. Arabidopsis accumulates much more free and glucosyl SA at $5^{\circ} \mathrm{C}$ than at $23^{\circ} \mathrm{C}$, contributing to cell growth inhibition at the chilling temperature (Scott et al. 2004). SA is differentially required for acquired and basal thermotolerance, depending on the developmental stage in Arabidopsis (Clarke et al. 2004; Larkindale et al. 2005), and a heat shock of $38^{\circ} \mathrm{C}$ induces a moderate increase of SA transiently (Scott et al. 2004). The amount of EDS1 and PAD4 transcripts is also temperature dependent, with lower accumulation at $28^{\circ} \mathrm{C}$ than at $22^{\circ} \mathrm{C}$ (Yang and Hua 2004). These components are therefore potential temperature sensors mediating temperature modulation of disease resistance. A feedback regulatory loop consisting of the $R$ gene, $E D S 1, P A D 4$, and SA may enforce the regulation of defense by temperature (Yang and Hua 2004).

In this study, we characterized the temperature effects on basal and $R$-mediated resistance against Pseudomonas syringae and specific viral effectors. All defense responses analyzed are found to be reduced at a moderately elevated temperature. We further tested candidate temperature-responsive regulators of plant defense responses including EDS1, PAD4, SA, and JA. These molecules, though each regulated by temperature or involved in temperature regulation, do not appear to be responsible for temperature sensitivity in defense response by themselves. Thus, temperature sensitivity is likely a general phenomenon in plant disease resistance against biotrophic and hemibiotrophic pathogens. Further study should identify one or more possible common mechanisms for this temperature sensitivity.

\section{RESULTS}

Temperature effects on basal resistance to a bacterial pathogen.

We investigated the interaction between Arabidopsis thaliana and the virulent pathogen Pseudomonas syringae pv. tomato DC3000 under the normal Arabidopsis growth temperature of $22^{\circ} \mathrm{C}$ and a warmer temperature of $28^{\circ} \mathrm{C}$. Wildtype 10-day-old seedlings were inoculated with $P$. syringae pv. tomato DC3000 by dipping and the bacterial growth in plants were analyzed 3 days postinoculation (dpi). DC3000 grew to $1.3 \times 10^{5} \mathrm{CFU}$ per milligram of plant tissue at $22^{\circ} \mathrm{C}$ and to 1.0 $\times 10^{6} \mathrm{CFU} / \mathrm{mg}$ at $28^{\circ} \mathrm{C}$ (Fig. 1A). The eightfold more growth of bacteria in plants at 28 than at $22^{\circ} \mathrm{C}$ indicates a large effect of temperature on this plant-pathogen interaction. Consistent with an increase of pathogen growth, infected plants developed more severe disease symptoms faster at 28 than at $22^{\circ} \mathrm{C}$ (data not shown).

To determine whether the difference in plants is due to an intrinsic growth rate difference of the bacterium at different temperatures, we analyzed its growth outside the plants. Cell density of $P$. syringae pv. tomato DC3000 was monitored after an overnight culture was inoculated in a rich liquid growth medium. From 8 to $18 \mathrm{~h}$ postinoculation (hpi), DC3000 grown at $28^{\circ} \mathrm{C}$ had a slightly greater (no more than $20 \%$ ) density than at $22^{\circ} \mathrm{C}$, while from $18 \mathrm{hpi}$ on, DC3000 grown at $22^{\circ} \mathrm{C}$ had a greater density than at $28^{\circ} \mathrm{C}$ (Fig. 1B). None of the timepoints showed differences at the two temperatures exceeding twofold.
Although the rich medium does not mimick the environment of plants, a higher growth rate at $28^{\circ} \mathrm{C}$ does not appear to be intrinsic for bacteria. As previous studies show a suppression in the secretion of toxins and effector proteins from pathogenic bacteria at $28^{\circ} \mathrm{C}$ (Budde et al. 1998; Palmer and Bender 1993; Smirnova et al. 2001; van Dijk et al. 1999), the increase of pathogen growth at $28^{\circ} \mathrm{C}$ in plants can not be explained by a higher virulence of DC3000 at higher temperatures either. Thus, the plant defense responses against DC3000 are likely suppressed by a higher growth temperature.

\section{Temperature effects on $\boldsymbol{R}$-mediated resistance to avirulent bacterial pathogens.}

We next analyzed effects of temperature on $R$ gene-mediated defense response against avirulent $P$. syringae pv. tomato DC3000 strains, using HR responses in the wild-type Arabidopsis Col-0 plants. Col-0 plants carry RPS2, RPM1, and RPS4, $R$ genes recognizing avirulent proteins AvrRpt2, AvrRpm1, and AvrRps4, respectively, and coding for the CCand TIR-type of NB-LRR proteins (Bent et al. 1994; Gassmann et al. 1999; Grant et al. 1995) and thus have a HR when encountering avirulent DC3000 strains expressing these effector proteins. Wild-type plants were grown at $22^{\circ} \mathrm{C}$ for 4 weeks or at $28^{\circ} \mathrm{C}$ for 3 weeks, until they reached a similar developmental stage before bolting. Bacterial strains were infiltrated into expanded leaves of these plants, and HR progression indicated by leaf collapse was followed at respective temperatures until the completion of HR or for $48 \mathrm{~h}$ after infiltration (Fig. 2A). For DC3000 with AvrRpt2, 50\% of the leaves underwent HR at $7 \mathrm{hpi}$ in $22^{\circ} \mathrm{C}$ and at $10 \mathrm{hpi}$ in $28^{\circ} \mathrm{C}$, while $80 \%$ of leaves showed $\mathrm{HR}$ at $12 \mathrm{hpi}$ in $22^{\circ} \mathrm{C}$ and at $18 \mathrm{hpi}$ in $28^{\circ} \mathrm{C}$. For
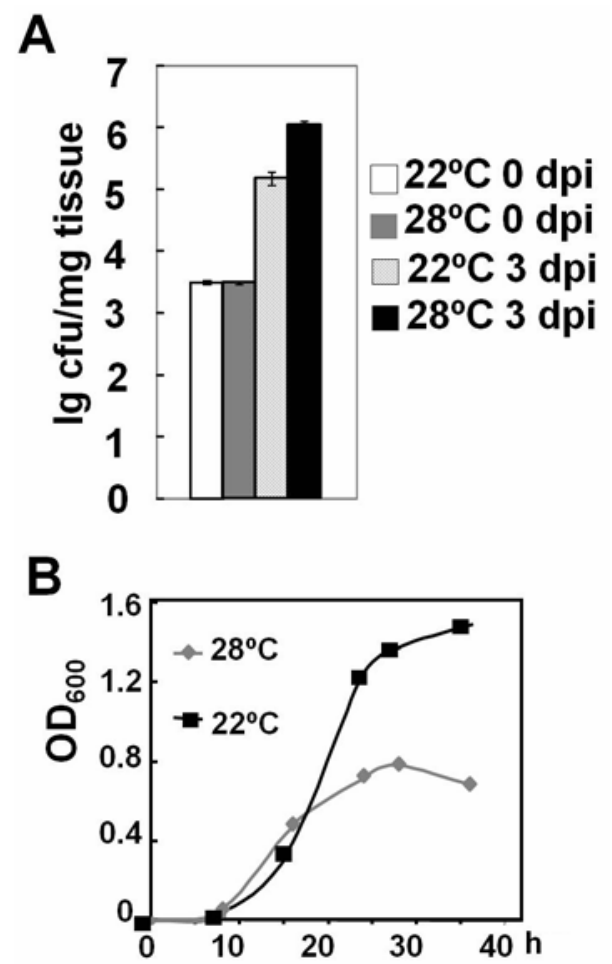

Fig. 1. Temperature effects on the growth of virulent bacterial pathogens in Arabidopsis thaliana and liquid medium. A, Growth of Pseudomonas syringae pv. tomato DC3000 at 22 and $28^{\circ} \mathrm{C}$ in wild-type Arabidopsis plants. Overnight culture $(0.1 \mathrm{ml})$ was inoculated into $100 \mathrm{ml}$ of culture at $0 \mathrm{~h}$. Error bars represent standard deviations of three biological repeats. A $t$-test shows a significant difference in DC 3000 growth at 22 and $28^{\circ} \mathrm{C}(P=$ $0.0011)$. B, Growth curve of DC3000 grown in liquid medium at 22 and $28^{\circ} \mathrm{C}$. The experiment was repeated three times, and similar growth curves were obtained. 
DC3000 with AvrRpm1, 50\% of the leaves underwent HR at 5 hpi in $22^{\circ} \mathrm{C}$ and at $8 \mathrm{hpi}$ in $28^{\circ} \mathrm{C}$, while $80 \%$ of leaves showed $\mathrm{HR}$ at $7 \mathrm{hpi}$ in $22^{\circ} \mathrm{C}$ and at 15 hpi in $28^{\circ} \mathrm{C}$. For DC3000 with AvrRps4, the difference at the two temperatures was more dramatic. At $22^{\circ} \mathrm{C}, 50 \%$ of leaves showed HR at 15 hpi and all showed HR at $36 \mathrm{hpi}$. In contrast, it took $48 \mathrm{~h}$ for $50 \%$ of leaves to show $\mathrm{HR}$ in $28^{\circ} \mathrm{C}$.

Correlating with a delay of $\mathrm{HR}$ in plants at $28^{\circ} \mathrm{C}$, bacterial growth in plants was increased at $28^{\circ} \mathrm{C}$ as compared with that at $22^{\circ} \mathrm{C}$. Wild-type Col- 0 seedlings grown at 22 and $28^{\circ} \mathrm{C}$ to a similar developmental stage were dip-innoculated with avirulent DC3000 strains. The propagation of bacteria was monitored in plants kept growing at these two temperatures. None of the three avirulent DC3000 strains had any growth at $3 \mathrm{dpi}$ over $0 \mathrm{dpi}$ at $22^{\circ} \mathrm{C}$ (Fig. 2B). In contrast, each amplified at least $10 \times$ at $28^{\circ} \mathrm{C}$. The growth of DC3000 with AvrRps4 was most affected by a warm condition and had almost $100 \times$ amplification over 3 days at $28^{\circ} \mathrm{C}$ (Fig. 2B).

Temperature effects on plant defense responses to viruses.

We next investigated the temperature effects of $R$ gene-mediated defense against viruses using HR as a readout. The $R x$ gene from potato confers resistance to Potato virus $X$ (PVX),
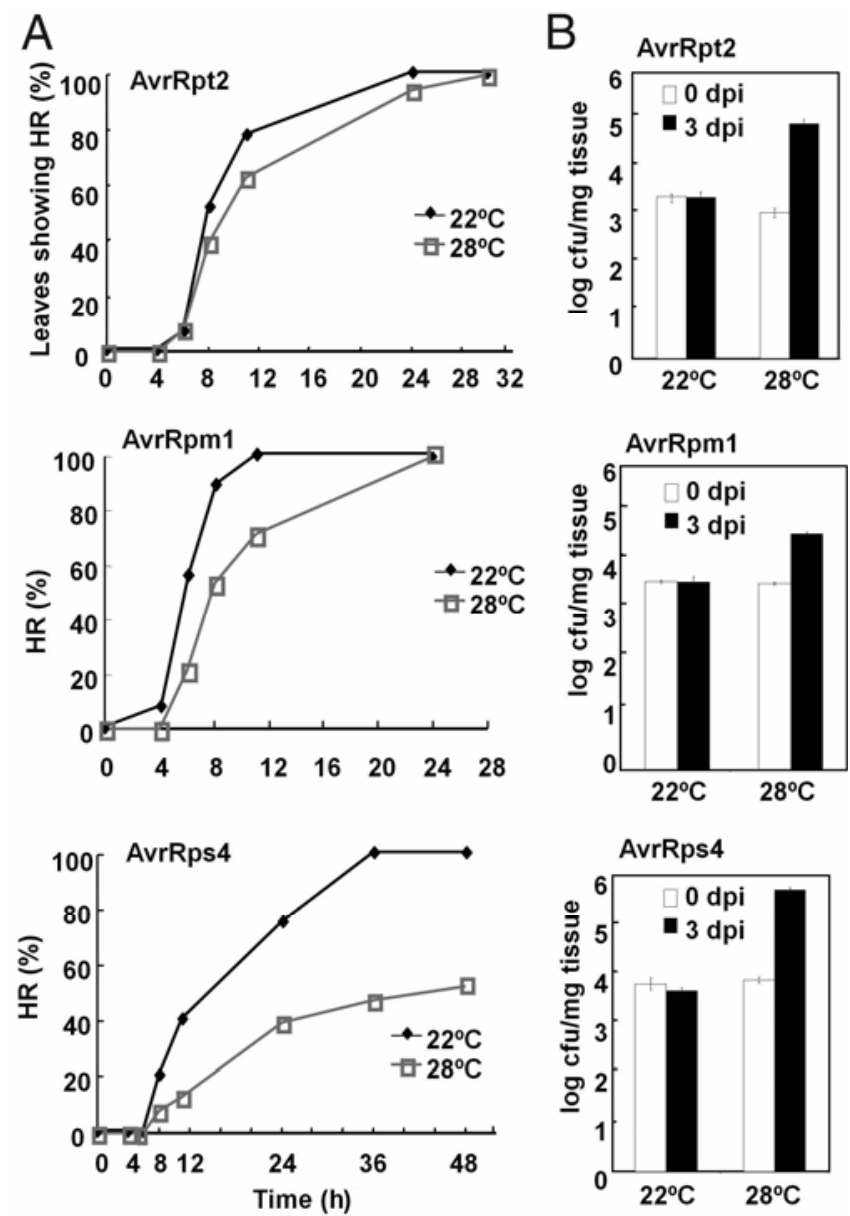

Fig. 2. Temperature effects on disease resistance to avirulent Pseudomonas syringae pv. tomato DC3000. A, Progression of hypersensitive responses (HR) in wild type (wt) Col-0 to DC3000 strains expressing AvrRpm1, AvrRpt2, and AvrRps 4 at 22 and $28^{\circ} \mathrm{C}$. Shown are the percentages of leaves exhibiting HR derived from at least 20 leaves. The experiments were repeated twice and similar results were obtained. B, Growth of DC3000 expressing AvrRpm1, AvrRpt2, and AvrRps4 in wild-type Arabidopsis Col- 0 at 22 and $28^{\circ} \mathrm{C}$. Error bars represent standard deviations of three biological repeats. The $t$-test shows that there is a significant amplification of these avirulent strains in Col- 0 at $28^{\circ} \mathrm{C}$ but not at $22^{\circ} \mathrm{C}$. and it encodes a CC-NB-LRR type of R protein (Bendahmane et al. 1999). The $N$ gene from tobacco mediates resistance to TMV, and it encodes a TIR-NB-LRR-type of $\mathrm{R}$ protein (Whitham et al. 1994). Both of them can trigger HR when they are coexpressed with their respective elicitors, the PVX coat protein (CP) and the TMV helicase fragment (p50) (Bendahmane et al. 1995; Erickson et al. 1999; Whitham et al. 1994).

Agrobacterium strains containing $\mathrm{Rx}$ and its elicitor $\mathrm{CP}$ were infiltrated into fully expanded leaves of $N$. benthamiana. These plants were grown in greenhouses with limited temperature control before acclimation at $22^{\circ} \mathrm{C}$ on lab bench for 1 day. Infiltrated plants were kept on the bench for $6 \mathrm{~h}$ before they were moved to controlled growth chambers. All other environmental conditions for these chambers were the same, except that the temperatures were set at 22,28 , and $30^{\circ} \mathrm{C}$. At $22^{\circ} \mathrm{C}$, HR induced by Rx and CP started to develop at 24 hpi and was completed at 48 hpi (Fig. 3A). In contrast, no HR could be seen at $30^{\circ} \mathrm{C}$ for up to 4 days (Fig. 3A). Interestingly, HR usually developed at about the same rate at 28 as at $22^{\circ} \mathrm{C}$, although occasionally a delay at $28^{\circ} \mathrm{C}$ was observed.

Disease resistance conferred by the $N$ gene is known to be temperature sensitive in N. tobacum (Samuel 1931) and tomato (Whitham et al. 1996). In N. benthamiana, we found a similar temperature sensitivity of $N$-mediated responses. HR was induced by the $N$ gene and its elicitor p50 at $22^{\circ} \mathrm{C}$ but not at 28 (Fig. 3B) or $30^{\circ} \mathrm{C}$ (data not shown). Thus both $R x$ - and $N$-mediated HR against viral proteins are suppressed by an elevated temperature in $N$. benthamiana, and the lower end of temperature necessary to inhibit HR appears to be slightly different for $R x$ and $N$.

\section{Analysis of the involvement of SA, EDS1, and PAD4 in high-temperature inhibition of resistance to virulent $P$. syringae pv. tomato $\mathrm{DC} 3000$.}

We asked whether effects of temperature on the accumulation of SA and transcripts of EDS1 and PAD4 confer tempera-

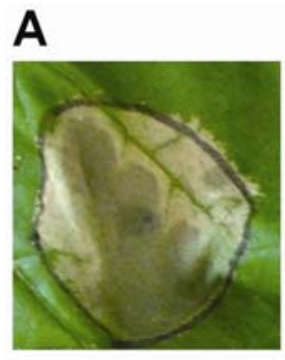

$22^{\circ} \mathrm{C}$

B

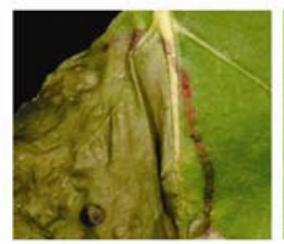

$22^{\circ} \mathrm{C}$

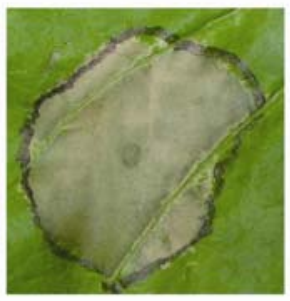

$28^{\circ} \mathrm{C}$

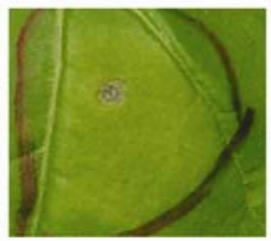

$28^{\circ} \mathrm{C}$
Fig. 3. High temperature inhibits the hypersensitive responses (HR) induced by $N$ and $R x$ in Nicotiana benthamiana. A, Temperature effects on $R x$ induced HR. Shown are representative leaves 3 days after agroinfiltration with $R x$ and $C P$ at $22^{\circ} \mathrm{C}, 28^{\circ} \mathrm{C}$, and $30^{\circ} \mathrm{C}$, respectively. B, Temperature effects on $N$-induced HR. Shown are representative leaves 3 days after agro-infiltration with $N$ and $p 50$ at 22 and $28^{\circ} \mathrm{C}$. Infiltrated areas were circled with black or red markers. The experiments were repeated at least three times and similar results were obtained. 
A

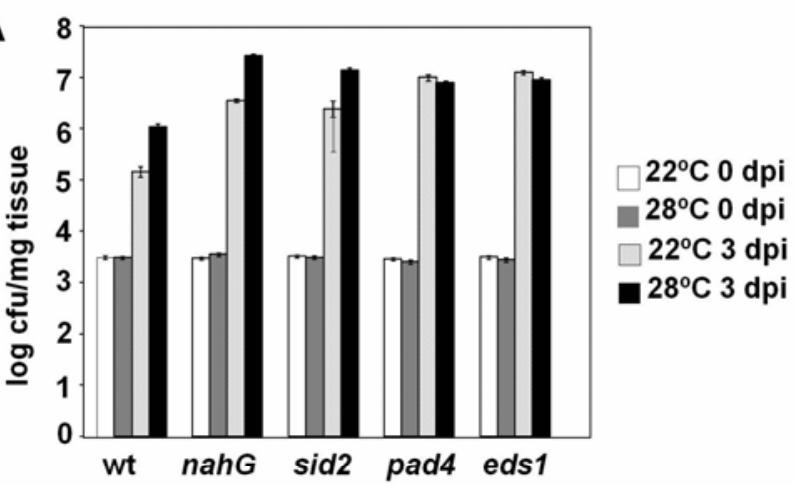

B

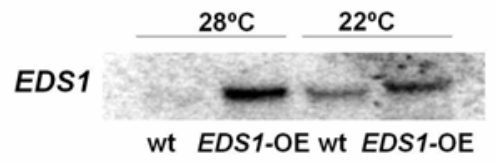

C

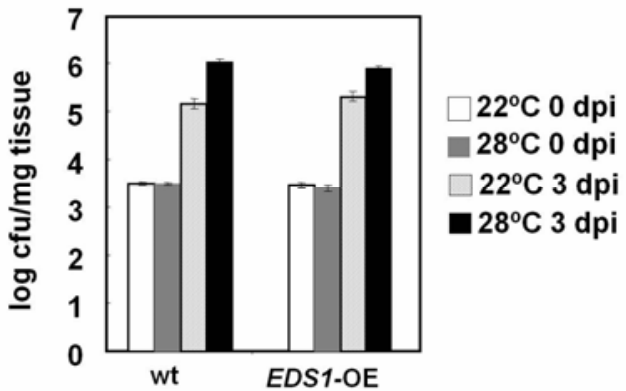

D

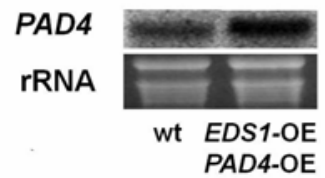

$\mathbf{E}$

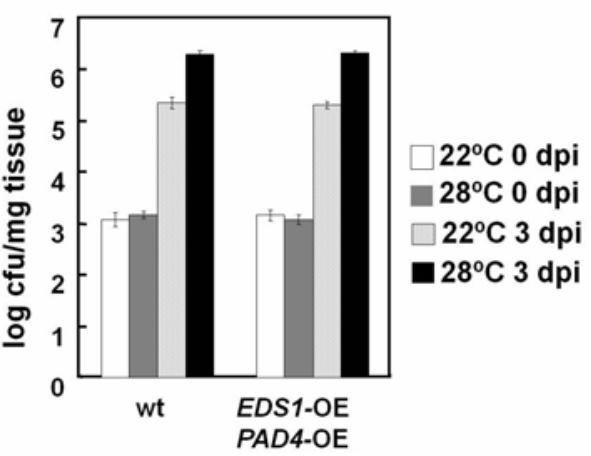

Fig. 4. Involvement of EDS1 and PAD4 in temperature modulation of defense response. A, Pseudomonas syringae pv. tomato DC3000 growth in wild type (wt), nahG, sid2, pad4, and eds 1 at 22 and $28^{\circ} \mathrm{C}$. The $t$-test shows significant differences between growth at 22 and $28^{\circ} \mathrm{C}$ for wt and $n a h G(P=0.004$ and 0.0003 , respectively $)$, and no significant differences between growth at 22 and $28^{\circ} \mathrm{C}$ for sid2, pad4, and eds $1(P=0.04,0.054$, and 0.034 , respectively). B, The expression of EDS1 in wt and the EDS1$\mathrm{OE}$ line at $28^{\circ} \mathrm{C}$, analyzed by an RNA blot. C, Growth of DC3000 in wt and the EDS1-OE line at 22 and $28^{\circ} \mathrm{C}$. The $t$-test shows no significant difference in growth at 3 days postinoculation between wt and EDS1-OE at 22 or $28^{\circ} \mathrm{C}(P=0.12$ and 0.23 , respectively). D, The expression of $P A D 4$ in wt and the EDS1-OE;PAD4-OE line at $28^{\circ} \mathrm{C}$ analyzed by an RNA blot. E, Growth of DC3000 in wt and EDS1-OE;PAD4-OE at 22 and $28^{\circ} \mathrm{C}$. The $t$-test shows no significant differences in growth at 22 and $28^{\circ} \mathrm{C}$ between wt and EDS1-OE; PAD4-OE ( $P=0.47$ and 0.21 , respectively). Error bars in the growth of DC3000 represent standard deviations of three biological repeats. ture sensitivity in disease resistance against $P$. syringae pv. tomato DC3000. First, the growth of virulent DC3000 at 22 and $28^{\circ} \mathrm{C}$ was compared in the wild-type Col-0, Col eds1-2 (Bartsch et al. 2006), pad4 (Glazebrook et al. 1996), sid2 (Dewdney et al. 2000), and the nahG transgenic plant (Bowling et al. 1997). The $n a h G$ transgenic contains a gene encoding a SA-degrading enzyme and the sid 2 mutant is deficient in SA accumulation after pathogen invasion (Wildermuth et al. 2001). Compared with the wild type, all three mutants and the $n a h G$ transgenic supported more bacterial growth at both temperatures, indicating an involvement of SA, EDS1, and PAD4 in basal defenses at both temperatures. The DC3000 strain grew better at $28^{\circ} \mathrm{C}$ than at $22^{\circ} \mathrm{C}$ in $n a h G$ and sid2, retaining the same temperature sensitivity as in the wild type. In contrast, it grew to the same extent at 22 and $28^{\circ} \mathrm{C}$ in the $e d s 1$ and pad4 mutants (Fig. 4A). These results suggest that EDS1 and PAD4 but not SA contribute to temperature sensitivity in basal defense responses to bacterial pathogen. Alternatively, the pathogen growth facilitated by defects in $e d s 1$ and pad 4 plants has reached the maximum capacity allowed in the plants at $22^{\circ} \mathrm{C}$, so that a further growth by the effect of a higher temperature is not detected. In this case, growth of bacteria in eds 1 and pad4 would appear to be temperature insensitive.

To further investigate the role of EDS1 and PAD4 in temperature modulation of plant defense, we tested temperature
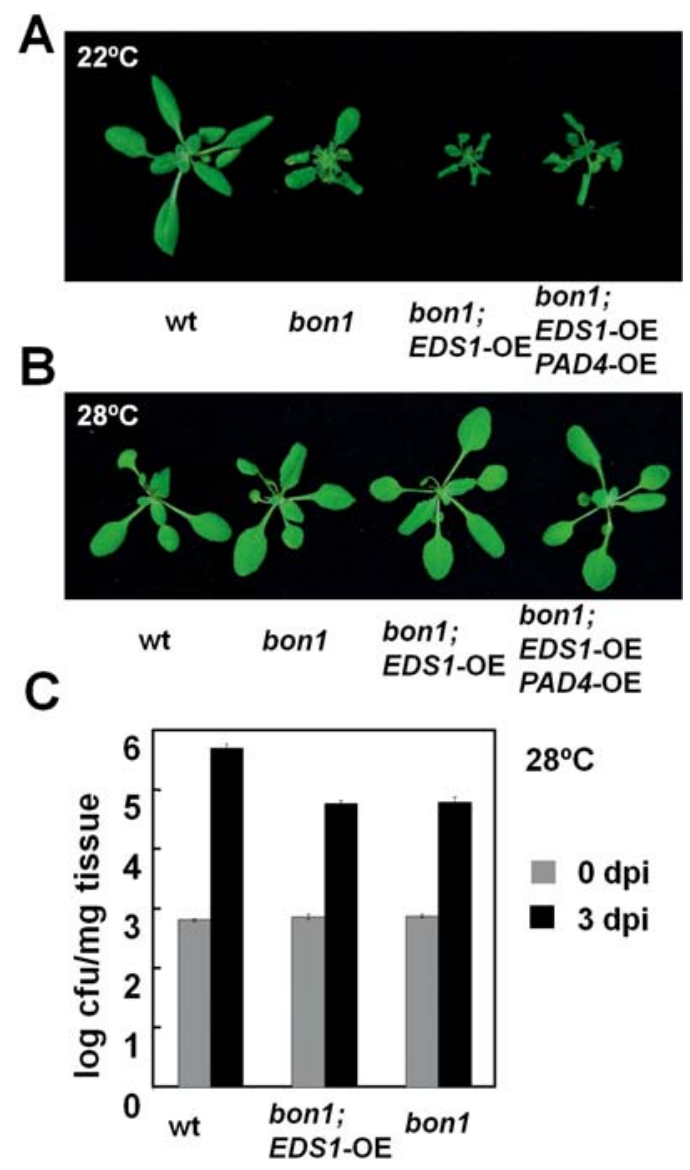

Fig. 5. Effects of overexpression of EDS1 and PAD4 on the bon1 phenotype. A, Growth phenotype of bon1;EDS1-OE and bon1;EDS1-OE PAD4-OE at $22^{\circ} \mathrm{C}$. Shown are wild type (wt), bonl-1, and two representative 25 -day-old transgenic plants. B, Growth phenotype of bon1;EDS1-OE and bon1;EDS1$\mathrm{OE} P A D 4-\mathrm{OE}$ at $28^{\circ} \mathrm{C}$. Shown are wt, bon 1-1, and two representative 20day-old transgenic plants. C, Growth of Pseudomonas syringae pv. tomato $\mathrm{DC} 3000$ in wt, bon1, and bon1;EDS1-OE at $28^{\circ} \mathrm{C}$. Error bars represent standard deviations of three biological repeats. The $t$-test shows a significant difference in growth at 3 days postinoculation between wt and bonl $(P=$ $0.0002)$ but not between bonl and bon1;EDS1-OE $(P=0.33)$. 
sensitivity of Arabidopsis plants expressing EDS1 at similar levels at two temperatures. The endogenous EDS1 genes have a lower expression at 28 than at $22^{\circ} \mathrm{C}$ (Yang and Hua 2004), and therefore, a strong constitutive $35 \mathrm{~S}$ promoter of Cauliflower mosaic virus was used to drive the expression of an EDS1 transgene. The p35S::EDS1 transgenic lines generated in Col-0 were subjected to RNA blot assay, and only one line out of seven was found to have an elevated EDS1 transcript at $28^{\circ} \mathrm{C}$ as compared with the wild type (Fig. 4B). This line has a comparable level of EDS1 transcripts at two temperatures, reversing the temperature regulation of the endogenous EDS1 genes (Fig. 4B). We named this line EDS1-OE and used it for further analysis. The EDS1-OE plant did not exhibit any morphological defects (data not shown). Further pathogen-growth testing revealed that it supported the same amount of growth of DC3000 as the wild type at both 22 and $28^{\circ} \mathrm{C}$ (Fig. 4C), suggesting that transcriptional overexpression of EDS1 in this line is not sufficient to confer temperature insensitivity to basal defense response against DC3000.

Because the EDS1 protein functions together with the PAD4 protein, we introduced into the EDS1-OE plant $p 35 S:: P A D 4$ in which the PAD4 gene is under the control of the strong $35 \mathrm{~S}$ promoter as well. One out of seven transgenic lines was found to have a higher $P A D 4$ transcript level at $28^{\circ} \mathrm{C}$ compared with the EDS1-OE line, and we named this line EDS1-OE;PAD4-OE (Fig. 4D). Resistance to $P$. syringae pv. tomato DC3000 was analyzed in this line, and no difference was observed between the EDS1-OE; PAD4-OE plant and the wild type at 22 or $28^{\circ} \mathrm{C}$ (Fig. 4E). This indicates that overexpression of EDS1 and PAD4 together at the transcriptional level in this transgenic line does not enhance basal resistance at either 22 or $28^{\circ} \mathrm{C}$ and it does not alter temperature sensitivity of disease resistance to virulent bacterial pathogen DC3000. More EDS1 and PAD4 overexpression lines are needed to verify this observation.

\section{Effects of $E D S 1$ and $P A D 4$ overexpression}

on temperature sensitivity of $\boldsymbol{R}$-mediated defense.

We next tested whether transcriptional upregulation of $E D S 1$ and $P A D 4$ can reverse the inhibitory effects of $28^{\circ} \mathrm{C}$ on $R$-mediated defense responses in two systems. The first system is HR mediated by RPS4, which exhibits a dramatic temperature sensitivity to $P$. syringae pv. tomato DC3000 expressing AvrRps4 (Fig. 2). The EDS1-OE;PAD4-OE plants grown at 22 and $28^{\circ} \mathrm{C}$ were infiltrated with DC3000 with AvrRps4, and HR was monitored at the two temperatures. No change in HR progression was observed in this line compared with the wild type at either temperature (data not shown). Thus, transcriptional overexpression of EDS1 and PAD4 is not sufficient to reverse the suppression on AvrRps4-triggered defense responses by high temperatures.

The second system in which we analyzed $R$-mediated defense response is the bonl (bonzail) mutant. The bonl mutant has an activation of a TIR-NB-LRR-type of $R$-like gene $S N C 1$ at 22 but not at $28^{\circ} \mathrm{C}$, resulting in a temperature-sensitive dwarf phenotype that can be easily scored. The EDS1-OE line was crossed to the bonl mutant to generate bon1;EDS1-OE plants, and EDS1-OE;PAD4-OE was crossed to bon1;EDS1$\mathrm{OE}$ to generate bonl;EDS1-OE PAD4-OE. At $22^{\circ} \mathrm{C}$, both bon1;EDS1-OE and bon1;EDS1-OE PAD4-OE plants exhibited a stronger dwarf phenotype compared with bonl (Fig. 5A) and this enhanced dwarf phenotype was more dramatic later in development (data not shown). The dwarf phenotype was, however, totally rescued at $28^{\circ} \mathrm{C}$, and no phenotypic difference was observed among the wild type, bon1, bon 1;EDS1-OE, and bon1;EDS1-OE PAD4-OE (Fig. 5B).

To confirm that disease resistance was indeed suppressed by $28^{\circ} \mathrm{C}$ in bon 1;EDS1-OE, we compared the growth of DC3000 in this line to those in bonl and the wild type at $28^{\circ} \mathrm{C}$. Plants were germinated at $22^{\circ} \mathrm{C}$ for 3 days (to facilitate synchronized germination and establishment of young bon 1;EDS1-OE seedlings) and were transferred to $28^{\circ} \mathrm{C}$ for 7 days before the pathogen tests were carried out at $28^{\circ} \mathrm{C}$. Under this condition, the bonl mutant supported slower growth of DC3000 compared with the wild type at $28^{\circ} \mathrm{C}$ (Fig. 5C). This slight increase of resistance in bon 1 was probably due to an activation of defense responses during the early growth at $22^{\circ} \mathrm{C}$, as previous study shows the same growth of DC3000 in bonl and the wild type grown constantly at $28^{\circ} \mathrm{C}$ (Yang and Hua 2004). Nevertheless, the bon 1;EDS1-OE plants behaved similarly to bonl
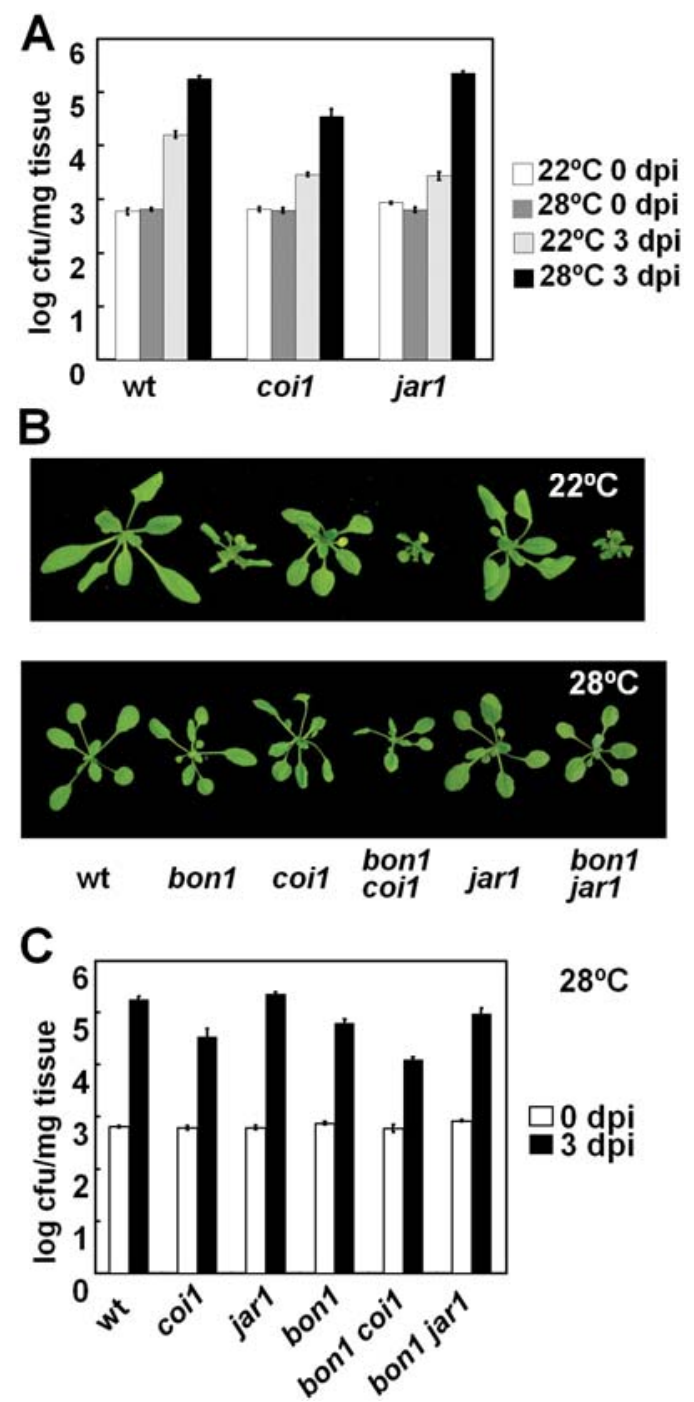

Fig. 6. The role of jasmonic acid in temperature modulation of defense responses. A, Growth of Pseudomonas syringae pv. tomato DC3000 in wild type (wt), coil, and jarl at 22 and $28^{\circ} \mathrm{C}$. The $t$-test shows a significant difference in growth at 3 days postinoculation (dpi) at $22^{\circ} \mathrm{C}$ between coil and wt $(P=0.0001)$ and between jarl and wt $(P=0.0007)$. There is a significant difference in growth at $3 \mathrm{dpi}$ at $28^{\circ} \mathrm{C}$ between coill and wt $(P=$ $0.0004)$ but not between jarl and wt $(P=0.02)$. B, Plant growth phenotype of wt, bon1, coil, bonlcoil, jarl, and bonljarl at 22 and $28^{\circ} \mathrm{C}$. $\mathbf{C}$, Growth of DC3000 in wt, coil, jarl, bon1, bon1coil, and bonljarl at $28^{\circ} \mathrm{C}$. The $t$-test shows a significant difference in growth at $3 \mathrm{dpi}$ at $28^{\circ} \mathrm{C}$ between bon 1 and wt $(P=0.0002)$ and between coil and wt $(P=0.0004)$ but not between jarl and wt $(P=0.02)$. The $t$-test also shows a significant difference in growth at $3 \mathrm{dpi}$ at $28^{\circ} \mathrm{C}$ between bonlcoil and bonl $(P=$ $0.0001)$ and between bonlcoil and coil $(P=0.001)$ but no significant difference between bonljarl and bonl $(P=0.02)$ and bonljarl and jarl $(P=$ $0.001)$. Error bars in the growth of DC3000 represent standard deviations of three biological repeats. 
(Fig. 5C), indicating that overexpression of EDS1 does not alter disease resistance of bonl at a higher temperature.

\section{Analysis of the role of the JA \\ in temperature modulation on defense response.}

A link between temperature responses and JA signaling was suggested from transcriptional profiling studies in which we compared Arabidopsis microarray data of a JA treatment $(1 \mathrm{~h}$ after $10 \mu \mathrm{M}$ of methyl jasmonate) (The Arabidopsis Information Resource [TAIR] accession number 1007965964) and a temperature-shift treatment (from 16 to $25^{\circ} \mathrm{C}$ for $9 \mathrm{~h}$ ) (Balasubramanian et al. 2006). Among the 34 genes with the highest induction by JA, 21 responded to the temperature shift treatment with at least twofold induction (Supplemental Table 1). No such coregulation was observed between responses to the temperature shift and responses to other hormones, including auxin, ethylene, and gibberellic acid (TAIR accession numbers 1007965859, 1005823581 and 1005823535, respectively) (data not shown). Because the SA signaling pathway is often antagonistic to the JA pathway, it is possible that a high temperature promotes JA signaling to repress SA signaling leading to a suppression of SA-mediated defense responses.

To test this hypothesis, we analyzed disease resistance to the virulent pathogen $P$. syringae pv. tomato DC3000 at 22 and $28^{\circ} \mathrm{C}$ in coil and jarl, two mutants defective in JA signaling. The coil mutant was shown to exhibit reduced susceptibility to DC3000 under normal growth conditions (Feys et al. 1994; Kloek et al. 2001). Consistent with these results, we found that both the coil and jarl mutants were more resistant to DC3000 than the wild type at $22^{\circ} \mathrm{C}$ (Fig. $6 \mathrm{~A}$ ). At $28^{\circ} \mathrm{C}$, coil is more disease resistant than the wild type and jarl is as resistant as the wild type (Fig. 6A). Both mutants supported more growth of $\mathrm{DC} 3000$ at $28^{\circ} \mathrm{C}$ than at $22^{\circ} \mathrm{C}$, indicating that they retain temperature sensitivity in defense responses. As COII mediates almost all JA responses, while JARl is responsible for part of the JA responses, enhanced resistance of the coil mutant compared with the wild type at $28^{\circ} \mathrm{C}$ suggests that JA still regulates defense responses at a higher temperature. Thus, the disease-resistance pathway mediated by JA likely functions in parallel to the temperature-sensitive disease-resistance pathway.

In addition, we analyzed the JA effects on the temperature sensitivity of the bonl mutant in which the $R$-like gene $S N C l$ is activated. Double mutants bonlcoil and bonljarl were constructed, and their phenotypes were analyzed at 22 and $28^{\circ} \mathrm{C}$. Both double mutants displayed more severe growth defects as compared with the bonl single mutant at $22^{\circ} \mathrm{C}$. Their dwarf phenotypes were largely rescued at $28^{\circ} \mathrm{C}$, although the bonljarl double mutant still displayed a weak dwarf phenotype (Fig. 6B). Their disease-resistance phenotypes were correlated with the growth phenotype. The bonl mutant had a slight increase of resistance to DC 3000 at $28^{\circ} \mathrm{C}$ compared with the wild type after 3 days of growth at $22^{\circ} \mathrm{C}$ followed by a 7 day growth at $28^{\circ} \mathrm{C}$. While the bonljarl double mutant supported pathogen growth to the same extent as bonl, the bonlcoil double mutant was more resistant to DC3000 than either the bonl or the coil single mutants at $28^{\circ} \mathrm{C}$ (Fig. 6C). Thus, bonl and coil have additive effects on resistance to DC3000 at $28^{\circ} \mathrm{C}$. This again supports the notion that the JAmediated resistance pathway functions in parallel to the temperature-sensitive resistance pathway.

\section{DISCUSSION}

Temperature has been implicated in affecting plant-pathogen interactions, and a higher growth temperature was observed to either increase or decrease disease resistance. This may reflect a differential influence by the same temperature variation on different plant-pathogen interactions. Alternatively, the observations might have been made at different temperature ranges or other environmental factors may not be well controlled, especially in the field. There appears to be a common theme that $R$ gene-mediated disease resistances including $\mathrm{HR}$ are often inhibited by an increase in growth temperature. In this study, we investigated the effect of a moderate increase in temperature above the normal on disease resistance in a controlled manner. We show that resistances to $P$. syringae pv. tomato DC3000 mediated by three $R$ genes were inhibited by a moderate elevation in temperature and the HR response to viral proteins from TMV and PVX were also suppressed by a warm condition. Temperature sensitivity is thus present in defense mediated by different classes of $\mathrm{R}$ proteins (Martin et al. 2003). The N, SNC1, and RPS4 proteins belong to the TIRNB-LRR class; RPM1, RPS2, and Rx belong to the CC-NBLRR class; Cf- 4 and Cf-9 belong to the LRR-TM (trans-membrane domain) class; and RPW8 is a unique TM-CC protein. In addition, we found that basal resistance to Pseudomonas syringae is also compromised by a moderate elevation of temperature. It is, therefore, probably a general phenomenon that disease resistances to biotrophic pathogens are inhibited by a mild elevation of the normal growth temperature.

We show that this temperature sensitivity lies mostly in the plant defense systems. The increase of bacterial growth in plants at elevated temperature can not be explained by variations in intrinsic bacterial growth rate or secretion of effector proteins at different temperatures. A slow HR is also unlikely to be caused by a slow accumulation of bacteria or effector proteins leading to a slower detection by plants. In fact, $P$. syringae pv. tomato DC3000 strains grow faster in plants at elevated temperature. That bacterial pathogens may secrete fewer effector proteins to trigger HR at a high temperature may contribute to the slow HR. Even so, it does not totally account for the slow or no HR at elevated temperatures. With expression of effector proteins directly in the plant cells, $\mathrm{HR}$ mediated by $\mathrm{N}$ and $\mathrm{Rx}$ is also inhibited by a higher temperature, indicating a deficiency in the plant defense system at elevated temperatures.

The evolutionary rationale for such an inhibition of disease resistance by an elevated temperature is unclear. This could be a result of coevolution of plants and their pathogens, as some pathogens are less virulent at a higher temperature. Almost all virulent genes of plant-pathogenic bacteria studied with respect to temperature exhibit increased transcription at temperatures below the respective growth optima; and these virulence determinants include phytotoxins, cell wall-degradating enzymes, and the bacterial type III secretion system (Smirnova et al. 2001). For instances, the production of coronatine by Pseudomonas syringae is maximal at $18^{\circ} \mathrm{C}$ and minimal at $28^{\circ} \mathrm{C}$ (Palmer and Bender 1993; Weingart et al. 2004) and several bacterial effector proteins are secreted most abundantly at temperatures between 18 to $22^{\circ} \mathrm{C}$ (van Dijk et al. 1999). It should also be noted that the resistances studied here are mostly against biotrophic pathogens living on live plants and it is yet to be tested whether plants have a higher resistance to necrotrophic pathogens at elevated temperatures, as host resistance to pathogens of these two lifestyles are often antagonistic. The temperature modulation might reflect a balance of defense against pathogens with different virulence at different temperature ranges.

Alternatively, this phenomenon might reflect a complex interaction between biotic and abiotic responses. Both heat shock protein 90 (HSP90) and heat shock cognate 70 (HSC70) are involved in plant defense responses, probably by performing chaperone functions together with SGT1 (Noel et al. 2007; Schulze-Lefert 2004). Temperature variation, even a moderate 
one, could change the expression of HSP and HSC and, therefore, affect the defense responses by altering $\mathrm{R}$ protein conformation or activities. Plants may also recruit these chaperon proteins to more essential cellular functions at elevated temperatures and thus compromise plant defense responses. Interestingly, overexpression of HSC70 is shown to enhance heat tolerance and to disable both basal and $R$-mediated disease resistance (Noel et al. 2007), supporting the hypothesis of a trade-off between biotic and abiotic responses.

This temperature sensitivity suggests that plant disease resistance could break down at elevated temperatures and an increase of a few degrees Celsius in temperature is sufficient to inhibit defense responses. It is not uncommon for plants in the fields to experience elevated temperatures (such as $28^{\circ} \mathrm{C}$ ) during the middle of the day. Whether that would be sufficient to inhibit disease resistance still waits to be determined, because our current studies are carried out under constant temperatures. Is there a window of time during early events in plant-pathogen interaction critical for elevated temperature to break down resistance or is a sustained high temperature required for this inhibition? Applying an elevated temperature for different lengths of time and at different phases of plantpathogen interaction will be needed to resolve this issue. In any case, elevated temperatures will likely facilitate the propagation of a number of plant diseases and it is important to understand the scope and the mechanisms of this temperature sensitivity.

It is not known how temperature modulates host disease resistance or whether similar mechanisms apply to its modulation of basal and $R$-mediated resistance. Does temperature affect recognition of the pathogen or does it affect the activities of defense signaling components? Temperature sensitivity of $\mathrm{N}$-mediated HR is shown to lie in the early event of HR, and elevated temperature is suggested to weaken the interaction between the virus and the host surveillance mechanism (Padgett et al. 1997). This is an attractive hypothesis that could potentially apply to both Avr recognition and pathogen-associated molecular pattern recognition. Consistent with this model, the temperature threshold required to inhibit HR or defense is different among disease resistances mediated by different $R$ genes. A temperature of $28^{\circ} \mathrm{C}$ is sufficient to suppress defense activated by $S N C l$ and $N$ but not $R x$, which requires $30^{\circ} \mathrm{C}$ for the inhibition. The same temperature of $28^{\circ} \mathrm{C}$ is more effective to inhibit growth of DC3000 through RPS4 than through $R P M 1$ or $R P S 2$. This might reflect a difference in temperature sensitivity of $\mathrm{R}$ protein recognition or activation. However, the molecular details of this early event remain to be identified and it needs to be tested whether it is, indeed, a common mechanism for temperature sensitivity.

It is equally plausible that some shared signaling components are responsible for temperature sensitivity, because disease resistances mediated by different classes of $\mathrm{R}$ proteins are modulated by temperature. This study tested the role of EDS1 and PAD4, which have a temperature-dependent transcript level, by elevating their expression at a high temperature with a strong $35 \mathrm{~S}$ promoter. However, very few transgenic plants with overexpression constructs achieved a high expression of these two genes at $28^{\circ} \mathrm{C}$. It remains to be determined whether few transgenic plants overexpress EDS1 and $P A D 4$ at $22^{\circ} \mathrm{C}$ as well. If so, their overexpression might have an adverse effect on plants and are therefore selected against in the transgenic generating process. If not, the EDS1 and PAD4 RNA transcripts themselves might be subject to temperature regulation. In this case, the EDS1-OE and PAD4-OE lines might have escaped this regulation by acquiring additional regulatory elements close to the transgene insertion site. Nevertheless, the transcripts of EDS1 and PAD4 are overexpressed in the line analyzed and their overexpression did not alter disease resistance at a higher temperature. Although more overexpression lines are needed for further analysis, this study suggests that temperature regulation of the transcript level of EDS1 and $P A D 4$ is not sufficient to cause temperature sensitivity of defense responses. However, we can not eliminate the possibility that the EDS1 protein activity (including its interaction with PAD4) could still be regulated by temperature to induce temperature sensitivity of defense.

This study also tested the role of two signaling molecules, SA and JA, in this temperature modulation, using mutants defective in their biosynthesis or signaling, and found that neither of them is sufficient to induce temperature-sensitivity by itself. Rather, it appears that SA fully mediates the temperature-sensitive pathway in disease resistance and JA functions in another independent pathway. Other shared signaling components in plant host defense could be candidates for such a 'temperature sensor.' Molecules like chaperone proteins and plant hormones such as abscisic acid and auxins could be tested. In addition, genetic screens for mutants defective in this modulation can be carried out to dissect this process. These studies to identify essential regulators should reveal the molecular mechanisms underlying temperature sensitivity of defense response and contribute to the understanding of temperature modulation of plant growth and development in general.

\section{MATERIALS AND METHODS}

\section{Plant growth.}

Arabidopsis seeds were sown on soil or petri dishes containing half-strength Murashige Skoog medium (Sigma, St. Louis) with $2 \%$ sucrose and $0.7 \%$ agar. Arabidopsis plants were grown in growth chambers (Conviron, Pembina, ND, U.S.A.) under fluorescent light $\left(100 \mu \mathrm{mol} \mathrm{m} \mathrm{m}^{-2} \mathrm{~s}^{-1}\right)$ and 50 to $60 \%$ relative humidity with controlled temperatures as specified. A photoperiod of 12-h light and 12-h darkness was used for disease resistance testing and a constant light condition was used otherwise. Nicotiana benthamiana plants were grown in the greenhouse for 3 to 4 weeks, followed by 1 day of growth on a lab bench at $22^{\circ} \mathrm{C}$ before being used for transient expression assays.

\section{Molecular biology manipulation.}

Basic molecular manipulations were carried out according to Sambrook and associates (1989). RNA was extracted from 3-week-old plants using Tri Reagent solution (Molecular Research Center, Cincinatti). Total RNAs of 20 or $30 \mu \mathrm{g}$ each were separated on gel and were transferred to Hybond nylon membrane (Amersham, Piscataway, NJ, U.S.A.). A ${ }^{32}$ P-labeled single-stranded antisense fragment was used for RNA blot hybridization. rRNA stained by ethidium bromide was used as a loading control.

\section{Generation of transgenic plants.}

To produce transgenic plants, the coding regions of the cDNAs of EDS1 and PAD4 were isolated by reverse transcription-polymerase chain reaction (RT-PCR) on total RNAs of the wild-type Arabidopsis. The cDNAs were then cloned into the pGreen0229 vector under the control of the strong promoter of $35 \mathrm{~S}$ promoter (pGreen website). The $p 35 S:: E D S 1$ and $p 35 S:$ : PAD4 overexpression constructs were transformed into Agrobacterium GV3101 (Koncz and Schell 1986) and, subsequently, into Arabidopsis plants by the floral dipping method (Clough and Bent 1998).

\section{Disease resistance assays.}

Bacterial growth in Arabidopsis was analyzed as described with some modifications (Tornero and Dangl 2001). Pseudo- 
monas syringae pv. tomato DC3000 was grown overnight on King's B medium and was resuspended at $10^{8} \mathrm{CFU} / \mathrm{ml}^{-1}$ in a solution of $10 \mathrm{mM} \mathrm{MgCl} 2$ and $0.02 \%$ Silwet L-77. Seedlings were grown at a defined temperature for 10 to 14 days, were dip-inoculated with bacteria, and were covered with a plastic dome for $1 \mathrm{~h}$ at room temperature $\left(22^{\circ} \mathrm{C}\right)$ before returning to their original growth temperature uncovered for 3 days. The amount of bacteria in plants was analyzed $1 \mathrm{~h}$ after dipping (day 0) and 3 days after dipping (day 3). The aerial parts of three inoculated seedlings were pooled as one sample, and three samples were collected for each genotype at one timepoint. Seedlings were ground in $1 \mathrm{ml}$ of $10 \mathrm{mM} \mathrm{MgCl}_{2}$, and serial dilutions of the ground tissue were used to determine the number of CFU per gram of leaf tissues.

\section{HR test.}

For the HR test in Arabidopsis, plants were initially grown at $22^{\circ} \mathrm{C}$ with a 12 -h day and 12 -h night for 3 weeks before they were acclimated at 22 and $28^{\circ} \mathrm{C}$, respectively, for 1 week. $P$. syringae pv. tomato DC3000 with avirulent genes were resuspended at $10^{8} \mathrm{CFU} / \mathrm{ml}$ and were infiltrated into expanded leaves of these plants. Infiltrated leaves were monitored for symptoms of cell collapse at 22 and $28^{\circ} \mathrm{C}$, respectively. For the HR test in $N$. benthamiana, Agrobacterium infiltrations were performed as described (Bendahmane et al. 2000; BurchSmith et al. 2007) with minor modification. Cells containing $\mathrm{Rx}$ and $\mathrm{CP}$ were each resuspended to a final concentration of an optical density at $600 \mathrm{~nm}\left(\mathrm{OD}_{600}\right)=0.2$. Cells containing $\mathrm{N}$ and p50 were resuspended to $\mathrm{OD}_{600}=1.8$ and $\mathrm{OD}_{600}=1.0$, respectively. Infiltrated plants were left on a bench at $22^{\circ} \mathrm{C}$ for $6 \mathrm{~h}$ before they were moved to different temperatures for HR monitoring.

\section{ACKNOWLEDGMENTS}

We are grateful to J. Parker, X. Dong, A. Collmer, P. Moffett, G. Jander for strains and plasmids and to anonymous reviewers for constructive comments. We thank the Arabidopsis Biological Resource Center for Arabidopsis mutant seeds. This research is supported by a grant from the United States Department of Agriculture to J. Hua.

\section{LITERATURE CITED}

Balasubramanian, S., Sureshkumar, S., Lempe, J., and Weigel, D. 2006. Potent induction of Arabidopsis thaliana flowering by elevated growth temperature. PLoS Genet. 2:e106. Published online.

Bartsch, M., Gobbato, E., Bednarek, P., Debey, S., Schultze, J.L., Bautor, J., and Parker, J. E. 2006. Salicylic acid-independent ENHANCED DISEASE SUSCEPTIBILITY1 signaling in Arabidopsis immunity and cell death is regulated by the monooxygenase FMO1 and the Nudix hydrolase NUDT7. Plant Cell 18:1038-1051.

Beckers, G. J., and Spoel, S. H. 2006. Fine-tuning plant defence signalling: Salicylate versus jasmonate. Plant Biol. (Stuttg) 8:1-10.

Bendahmane, A., Kohn, B. A., Dedi, C., and Baulcombe, D. C. 1995. The coat protein of Potato virus $\mathrm{X}$ is a strain-specific elicitor of Rx1-mediated virus resistance in potato. Plant J. 8:933-941.

Bendahmane, A., Kanyuka, K., and Baulcombe, D. C. 1999. The $R x$ gene from potato controls separate virus resistance and cell death responses. Plant Cell 11:781-792.

Bendahmane, A., Querci, M., Kanyuka, K., and Baulcombe, D. C. 2000. Agrobacterium transient expression system as a tool for the isolation of disease resistance genes: Application to the $R \times 2$ locus in potato. Plant $\mathrm{J}$. 21:73-81.

Bent, A. F., Kunkel, B. N., Dahlbeck, D., Brown, K. L., Schmidt, R., Giraudat, J., Leung, J., and Staskawicz, B. J. 1994. RPS2 of Arabidopsis thaliana: A leucine-rich repeat class of plant disease resistance genes. Science 265:1856-1860.

Bowling, S. A., Clarke, J. D., Liu, Y., Klessig, D. F., and Dong, X. 1997. The cpr 5 mutant of Arabidopsis expresses both NPR1-dependent and NPR1-independent resistance. Plant Cell 9:1573-1584.

Browder, L. E. 1985. Parasite:host:environment specificity in the cereal rusts. Annu. Rev. Phytopathol. 23:201-222.
Budde, I. P., Rohde, B. H., Bender, C. L., and Ullrich, M. S. 1998. Growth phase and temperature influence promoter activity, transcript abundance, and protein stability during biosynthesis of the Pseudomonas syringae phytotoxin coronatine. J. Bacteriol. 180:1360-1367.

Burch-Smith, T. M., Schiff, M., Caplan, J. L., Tsao, J., Czymmek, K., and Dinesh-Kumar, S. P. 2007. A novel role for the TIR domain in association with pathogen-derived elicitors. PLoS Biol. 5:e68. Published online.

Chini, A., Fonseca, S., Fernandez, G., Adie, B., Chico, J. M., Lorenzo, O. Garcia-Casado, G., Lopez-Vidriero, I., Lozano, F. M., Ponce, M. R., Micol, J. L., and Solano, R. 2007. The JAZ family of repressors is the missing link in jasmonate signalling. Nature 448:666-671.

Chisholm, S. T., Coaker, G., Day, B., and Staskawicz, B. J. 2006. Host-microbe interactions: Shaping the evolution of the plant immune response. Cell 124:803-814.

Clarke, S. M., Mur, L. A., Wood, J. E., and Scott, I. M. 2004. Salicylic acid dependent signaling promotes basal thermotolerance but is not essential for acquired thermotolerance in Arabidopsis thaliana. Plant J. 38:432-447.

Clough, S. J., and Bent, A. F. 1998. Floral dip: A simplified method for Agrobacterium-mediated transformation of Arabidopsis thaliana. Plant J. 16:735-743.

Colhoun, J. 1973. Effects of environmental factors on plant disease. Annu. Rev. Phytopathol. 11:343-364.

Dangl, J. L., and Jones, J. D. 2001. Plant pathogens and integrated defence responses to infection. Nature 411:826-833.

de Jong, C. F., Takken, F. L. W., Cai, X., de Wit, P. J. G. M., and Joosten, M. H. A. J. 2002. Attenuation of Cf-mediated defense responses at elevated temperatures correlates with a decrease in elicitor-binding sites. Mol. Plant-Microbe Interact. 15:1040-1049.

Dewdney, J., Reuber, T. L., Wildermuth, M. C., Devoto, A., Cui, J., Stutius, L. M., Drummond, E. P., and Ausubel, F. M. 2000. Three unique mutants of Arabidopsis identify eds loci required for limiting growth of a biotrophic fungal pathogen. Plant J. 24:205-218.

Dropkin, V. H. 1969. The necrotic reaction of tomato and other hosts resistant to Meloidogyne: Reversal by temperature. Phytopathology 59:1632-1637.

Durrant, W. E., and Dong, X. 2004. Systemic acquired resistance. Annu. Rev. Phytopathol. 42:185-209.

Erickson, F. L., Holzberg, S., Calderon-Urrea, A., Handley, V., Axtell, M., Corr, C., and Baker, B. 1999. The helicase domain of the TMV replicase proteins induces the $\mathrm{N}$-mediated defence response in tobacco. Plant J. 18:67-75.

Evans, N., Baierl, A., Semenov, M. A., Gladders, P., and Fitt, B. D. 2008. Range and severity of a plant disease increased by global warming. J. R. Soc. Interface 5:525-531.

Feys, B., Benedetti, C. E., Penfold, C. N., and Turner, J. G. 1994. Arabidopsis mutants selected for resistance to the phytotoxin coronatine are male sterile, insensitive to methyl jasmonate, and resistant to a bacterial pathogen. Plant Cell 6:751-759.

Garrett, K. A., Dendy, S. P., Frank, E. E., Rouse, M. N., and Travers, S. E. 2006. Climate change effects on plant disease: Genomes to ecosystems. Annu. Rev. Phytopathol. 44:489-509.

Gassmann, W., Hinsch, M. E., and Staskawicz, B. J. 1999. The Arabidopsis RPS4 bacterial-resistance gene is a member of the TIR-NBS-LRR family of disease-resistance genes. Plant J. 20:265-277.

Glazebrook, J. 2005. Contrasting mechanisms of defense against biotrophic and necrotrophic pathogens. Annu. Rev. Phytopathol. 43:205-227.

Glazebrook, J., Rogers, E. E., and Ausubel, F. M. 1996. Isolation of Arabidopsis mutants with enhanced disease susceptibility by direct screening. Genetics 143:973-982.

Grant, M. R., Godiard, L., Straube, E., Ashfield, T., Lewald, J., Sattler, A., Innes, R. W., and Dangl, J. L. 1995. Structure of the Arabidopsis RPM1 gene enabling dual specificity disease resistance. Science 269:843-846.

Hwang, C. F., Bhakta, A. V., Truesdell, G. M., Pudlo, W. M., and Williamson, V. M. 2000. Evidence for a role of the $\mathrm{N}$ terminus and leucine-rich repeat region of the $M i$ gene product in regulation of localized cell death. Plant Cell 12:1319-1329.

Jablonska, B., Ammiraju, J. S., Bhattarai, K. K., Mantelin, S., Martinez de Ilarduya, O., Roberts, P. A., and Kaloshian, I. 2007. The Mi-9 gene from Solanum arcanum conferring heat-stable resistance to root-knot nematodes is a homolog of Mi-1. Plant Physiol. 143:1044-1054.

Jones, J. D., and Dangl, J. L. 2006. The plant immune system. Nature 444:323-329.

Kloek, A. P., Verbsky, M. L., Sharma, S. B., Schoelz, J. E., Vogel, J., Klessig, D. F., and Kunkel, B. N. 2001. Resistance to Pseudomonas syringae conferred by an Arabidopsis thaliana coronatine-insensitive (coil) mutation occurs through two distinct mechanisms. Plant J. 26:509-522.

Koncz, C., and Schell, J. 1986. The promoter of the TL-DNA gene 5 controls the tissue-specific expression of chimeric genes carried by a novel 
type of Agrobacterium binary vector. Mol. Gen. Genet. 204:383-396.

Kunkel, B. N., and Brooks, D. M. 2002. Cross talk between signaling pathways in pathogen defense. Curr. Opin. Plant Biol. 5:325-331.

Larkindale, J., Hall, J. D., Knight, M. R., and Vierling, E. 2005. Heat stress phenotypes of Arabidopsis mutants implicate multiple signaling pathways in the acquisition of thermotolerance. Plant Physiol. 138:882897.

Martin, G., Bogdanove, A., and Sessa, G. 2003. Understanding the functions of plant disease resistance proteins. Annu. Rev. Plant Biol. 54:23-61.

Melotto, M., Underwood, W., Koczan, J., Nomura, K., and He, S. Y. 2006. Plant stomata function in innate immunity against bacterial invasion. Cell 126:969-980.

Noel, L. D., Cagna, G., Stuttmann, J., Wirthmuller, L., Betsuyaku, S., Witte, C. P., Bhat, R., Pochon, N., Colby, T., and Parker, J. E. 2007. Interaction between SGT1 and cytosolic/nuclear HSC70 chaperones regulates Arabidopsis immune responses. Plant Cell 19:4061-4076.

Padgett, H. S., Watanabe, Y., and Beachy, R. N. 1997. Identification of the TMV replicase sequence that activates the $N$ gene-mediated hypersensitive response. Mol. Plant Microbe Interact. 10:709-715.

Palmer, D. A., and Bender, C. L. 1993. Effects of environmental and nutritional factors on production of the polyketide phytotoxin coronatine by Pseudomonas syringae pv. glycinea. Appl. Environ. Microbiol. 59:1619-1626.

Sambrook, J., Fritsch, E. F., and Maniatis, T. 1989. Molecular Cloning: A Laboratory Manual. Cold Spring Harbor Laboratory Press, Cold Spring Harbor, NY, U.S.A.

Samuel, G. 1931. Some experiments on inoculating methods with plant viruses, and on local lesions. Ann. Appl. Biol. 18:494-507.

Schulze-Lefert, P. 2004. Plant immunity: The origami of receptor activation. Curr. Biol. 14:R22-24.

Scott, I. M., Clarke, S. M., Wood, J. E., and Mur, L. A. 2004. Salicylate accumulation inhibits growth at chilling temperature in Arabidopsis. Plant Physiol. 135:1040-1049.

Smirnova, A., Li, H., Weingart, H., Aufhammer, S., Burse, A., Finis, K. Schenk, A., and Ullrich, M. S. 2001. Thermoregulated expression of virulence factors in plant-associated bacteria. Arch. Microbiol. 176:393-399.

Spoel, S. H., and Dong, X. 2008. Making sense of hormone crosstalk during plant immune responses. Cell Host Microbe 3:348-351.

Spoel, S. H., Koornneef, A., Claessens, S. M., Korzelius, J. P., Van Pelt, J. A., Mueller, M. J., Buchala, A. J., Metraux, J. P., Brown, R., Kazan, K., Van Loon, L. C., Dong, X., and Pieterse, C. M. 2003. NPR1 modulates cross-talk between salicylate- and jasmonate-dependent defense pathways through a novel function in the cytosol. Plant Cell 15:760-770.

Spoel, S. H., Johnson, J. S., and Dong, X. 2007. Regulation of tradeoffs between plant defenses against pathogens with different lifestyles. Proc. Natl. Acad. Sci. U.S.A. 104:18842-18847.

Staswick, P. E., Tiryaki, I., and Rowe, M. L. 2002. Jasmonate response locus JAR1 and several related Arabidopsis genes encode enzymes of the firefly luciferase superfamily that show activity on jasmonic, salicylic, and indole-3-acetic acids in an assay for adenylation. Plant Cell 14:1405-1415

Szittya, G., Silhavy, D., Molnar, A., Havelda, Z., Lovas, A., Lakatos, L., Banfalvi, Z., and Burgyan, J. 2003. Low temperature inhibits RNA silencing-mediated defence by the control of siRNA generation. EMBO (Eur. Mol. Biol. Organ.) J. 22:633-640

Thines, B., Katsir, L., Melotto, M., Niu, Y., Mandaokar, A., Liu, G., Nomura, K., He, S. Y., Howe, G. A., and Browse, J. 2007. JAZ repressor proteins are targets of the $\mathrm{SCF}(\mathrm{COI} 1)$ complex during jasmonate signalling. Nature 448:661-665.

Tornero, P., and Dangl, J. L. 2001. A high-throughput method for quantifying growth of phytopathogenic bacteria in Arabidopsis thaliana. Plant J.28, 475-481.

Turner, J. G., Ellis, C., and Devoto, A. 2002. The jasmonate signal pathway. Plant Cell 14 (Suppl):S153-164.

van Dijk, K., Fouts, D. E., Rehm, A. H., Hill, A. R., Collmer, A., and Alfano, J. R. 1999. The Avr (effector) proteins HrmA (HopPsyA) and AvrPto are secreted in culture from Pseudomonas syringae pathovars via the Hrp (type III) protein secretion system in a temperature- and pH-sensitive manner. J. Bacteriol. 181:4790-4797.

Weingart, H., Stubner, S., Schenk, A., and Ullrich, M. S. 2004. Impact of temperature on in planta expression of genes involved in synthesis of the Pseudomonas syringae phytotoxin coronatine. Mol. Plant-Microbe Interact. 17:1095-1102.

Whitham, S., Dinesh-Kumar, S. P., Choi, D., Hehl, R., Corr, C., and Baker, B. 1994. The product of the tobacco mosaic virus resistance gene $N$ : Similarity to toll and the interleukin-1 receptor. Cell 78:1101-1115.

Whitham, S., McCormick, S., and Baker, B. 1996. The $N$ gene of tobacco confers resistance to Tobacco mosaic virus in transgenic tomato. Proc. Natl. Acad. Sci. U.S.A. 93:8776-8781.

Wiermer, M., Feys, B. J., and Parker, J. E. 2005. Plant immunity: The EDS1 regulatory node. Curr. Opin. Plant Biol. 8:383-389.

Wildermuth, M. C., Dewdney, J., Wu, G., and Ausubel, F. M. 2001. Isochorismate synthase is required to synthesize salicylic acid for plant defence. Nature 414:562-565.

Xiao, S., Brown, S., Patrick, E., Brearley, C., and Turner, J. G. 2003. Enhanced transcription of the Arabidopsis disease resistance genes RPW8.1 and $R P W 8.2$ via a salicylic acid-dependent amplification circuit is required for hypersensitive cell death. Plant Cell 15:33-45.

Yang, S., and Hua, J. 2004. A haplotype-specific resistance gene regulated by BONZAI1 mediates temperature-dependent growth control in Arabidopsis. Plant Cell 16:1060-1071.

\section{AUTHOR-RECOMMENDED INTERNET RESOURCE}

pGreen website: www.pgreen.ac.uk 